DOI http://dx.doi.org/10.31571/edukasi.v18i1.1600

Link https://journal.ikippgriptk.ac.id/index.php/edukasi/article/view/1600

\title{
PERSEPSI MAHASISWA TENTANG KOMPETENSI DOSEN TERHADAP HASIL BELAJAR MATA KULIAH LISTRIK DAN ELEKTRONIKA OTOMOTIF
}

\author{
Rifdarmon $^{1}$, Ambiyar ${ }^{2}$, Wakhinuddin ${ }^{3}$ \\ ${ }^{1,3}$ Teknik Otomotif, Fakultas Teknik, Universitas Negeri Padang, \\ Jalan Prof. Dr. Hamka, Air Tawar, Kota Padang. \\ ${ }^{2}$ Teknik Mesin, Fakultas Teknik, Universitas Negeri Padang, \\ Jalan Prof. Dr. Hamka, Air Tawar, Kota Padang. \\ 1e-mail: rifdarmon@ft.unp.ac.id
}

\begin{abstract}
Abstrak
Tujuan penelitian untuk menganalisis hubungan kompetensi dosen dalam mengajar terhadap hasil belajar mahasiswa. Metode yang digunakan adalah metode kuantitatif dengan jenis penelitian ex post facto. Responden penelitian sebanyak 38 orang. Penelitian menggunakan teknik pengumpulan data berupa angket yang disebar kepada mahasiswa yang mengikuti mata kuliah Listrik dan Elektronika Otomotif. Alat pengumpul data adalah Google document. Teknik analisis data menggunakan korelasi berganda. Hasil penelitian menunjukkan bahwa terdapat hubungan antara kompetensi dosen dalam mengajar dan hasil belajar mahasiswa.
\end{abstract}

Kata Kunci: kompetensi dosen, hasil belajar, ex post facto.

\begin{abstract}
The purpose of this research was to analyze the relationship between lecturers' competences in teaching and student learning outcomes. The method used a quantitative with the type of ex post facto research. Research respondents were 38 people. The study used a data collection technique in the form of a questionnaire distributed to students who took the Electrical and Automotive Electronics course. Data collection tool was Google document. Data analysis techniques used multiple correlation. The results showed that there was a relationship between lecturers' competences in teaching and student learning outcomes.
\end{abstract}

Keywords: lecturers' competences, learning outcomes, ex post facto. 